\section{Relay-Intercropping Does Not Reduce Strawberry Yield in an Annual-hill Production System}

\author{
John R. Duval ${ }^{1}$
}

Additional index words. Fragaria $\times$ ananassa, double cropping

$\mathrm{R}$ elay-intercropping is the production of two crops in the same field in a single year, with both crops concurrently in the field for some period of time during which the primary crop has a competitive advantage over the secondary crop. The primary crop suppresses the growth of the second crop with minimal competitive effects on primary crop yield (Coolman and Hoyt, 1993). In contrast, double-cropping is the production of two crops in the same field in a single year but the crops are produced at separate times. Double cropping of vegetables (Brown et al., 1985; Hanna, 2000) and strawberry (Fragaria $\times$ ananassa) with muskmelon (Cucumis melo) (Poling and Lamont, 1991) on plastic mulch has been found to be a profitable management strategy for producers. Relay-intercropping of strawberries grown in a winter annualhill production system has the potential to maximize inputs of land preparation, plastic mulch, and drip-irrigation in fumigated soil.

Planting of secondary crops takes place 4 to 5 weeks before the end of the strawberry production season, dependent on strawberry cultivar. Common secondary crops are muskmelon, summer squash (Cucurbita pepo), pickling cucumber (Cucumis sativus), and bell pepper (Capsicum annumm). Once strawberry production becomes unprofitable due to unfavorable market prices and poor fruit quality, leaves and crowns are removed by hand to allow unimpeded growth of the secondary crop. By using this practice, growers are able to harvest and market secondary crops earlier than if these crops are

Gulf Coast Research and Education Center, University of Florida, 14625 County Rd. 672, Wimauma FL, 33598.

Florida Agricultural Experiment Station Journal Series R- 10710 .

${ }^{1}$ To whom reprint requests should be addressed. E-mail address: jrduval@ifas.ufl.edu not intercropped. However, the effect of relay-intercropping these secondary crops with strawberry has not been documented.

In addition, strawberry is an insurable crop. However, insurance policies may not allow for relay-intercropping of strawberry. The purpose of this study was to determine the effect of intercropping strawberry with the most common secondary crops.

\section{Material and methods}

A study was instituted at the Gulf Coast Research and Education Center, Dover, Fla., on a Seffner fine sand (sandy, siliceous, hyperthermic, Quartzipsammentic Haplumbrepts) to examine the effect of relay-intercropping strawberry with 'Gentry' summer squash and 'Napoleon' pickling cucumber from seed, and 'Athena' muskmelon and 'Wizzard' bell pepper from transplants, compared to nonintercropped strawberries. Plantings of secondary crops occurred on $28 \mathrm{Feb}$., 7 Mar., and 14 Mar. 2003 and 2004 into a 16-plant plot of 'Strawberry Festival' strawberries spaced 15 inches apart in row and 12 inches between rows. These dates give a representation of the typical period when commercial growers initiate relay intercropping. Plots were arranged in a complete randomized block design replicated three times. Muskmelon spacing was 30 inches on the center of the bed; summer squash and pickling cucumber spacing was 15 inches on the center of the bed; and bell pepper spacing was a double row on the bed 15 inches between plants and 10 inches between rows. Fertigation was increased by $10 \%$ to $0.83 \mathrm{lb} /$ acre of nitrogen per day to compensate for additional plants in the field. Pesticide applications were adjusted to account for label requirements for all crops (Legard et al., 2003) and discontinued when no suitable material was available. Strawberry yield data were collected twice weekly from each plot from the time of planting the secondary crop until the end of the harvest period. Marketable yield, number of marketable berries, and cull fruit, based on deformity, size, and disease incidence were recorded until 31 Mar. 2003 and 1 Apr. 2004, which corresponded to the end of both seasons for commercial distant shippers. Secondary crops were destroyed at the end of the experiment due to space and capability limitations at the site. Economic analysis was based upon crop budgets by Smith and Taylor (2003a, 2003b, 2003c, 2003d) and Hewitt (2003). Budgets were adjusted for plant densities and comparison against a single crop system. Since year-by-treatment interactions were nonsignificant for measured parameters, data were combined across years and analyzed by secondary crop and planting date using analysis of variance (SAS Institute, Cary, N.C.)

\section{Results and discussion}

No differences were detected among treatments $(P<0.05)$ for yield (Table 1), number of fruit or cull fruit (data not presented). The majority of fruit $(>50 \%)$ were harvested during the second week of March both years. Overall, yields were consistent with commercial yields during this period. These data suggest that there was no detriment to strawberry fruit yield from relay-intercropping with summer squash, pickling cucumber, muskmelon, or bell pepper planted up to $31 \mathrm{~d}$ before the end of fruit harvest. This is only true when the strawberry population of the field has been maintained and no plants removed for the planting of the second crop. If strawberry plants are removed, a corresponding decrease in yield per acre may be expected. Although not directly measured in these trials, ease of berry

\begin{tabular}{llll}
\hline $\begin{array}{l}\text { Units } \\
\text { To convert U.S. to SI, } \\
\text { multiply by }\end{array}$ & U.S. unit & SI unit & $\begin{array}{l}\text { To convert SI to U.S., } \\
\text { multiply by }\end{array}$ \\
\hline 0.4047 & acre(s) & $\mathrm{ha}$ & 2.4711 \\
2.5400 & inch(es) & $\mathrm{cm}$ & 0.3937 \\
0.4536 & $\mathrm{lb}$ & $\mathrm{kg}$ & 2.2046
\end{tabular}


Table 1. Combined yield of 'Strawberry Festival' strawberries relay-intercropped with 'Gentry' summer squash and 'Napoleon' pickling cucumber from seed, and 'Wizzard' bell pepper and 'Athena' muskmelon from transplants planted on three dates during the 2002-03 and 2003-04 growing seasons. Data represent harvested marketable yield from the date of planting of secondary crop.

Yield

(no. 12-lb flats/acre)

\begin{tabular}{lccc}
\cline { 2 - 4 } & \multicolumn{3}{c}{ Date of secondary crop planting } \\
\cline { 2 - 4 } & $\mathbf{2 8 \text { Feb. }}$ & 7 Mar. & 14 Mar. \\
\hline Control & $761^{\mathrm{y}, \mathrm{x}}$ & 757 & 365 \\
Pickling cucumber & 754 & 774 & 391 \\
Summer squash & 634 & 793 & 325 \\
Bell peppers & 751 & 800 & 396 \\
Muskmelon & 785 & 736 & 376 \\
$P$ & 0.4268 & 0.9601 & 0.9712 \\
LSD $(P<0.05)$ & 171.8 & 239.0 & 228.2 \\
CV & 21.34 & 28.20 & 56.42 \\
\hline
\end{tabular}

${ }^{z}$ One $12-\mathrm{lb}(0.45 \mathrm{~kg})$ flat $/$ acre $=13.4502 \mathrm{~kg} \cdot \mathrm{ha}^{-1}$

Values represent the mean value of three replicate plots harvested during the 2002-03 and 2003-04 production seasons.

xBerries were harvested until 31 Mar. 2003 and I Apr. 2004, which represent the end of commercial production both years.

harvest was not greatly affected by the presence of any secondary crop.

Relay intercropping removes the cost of plastic mulch and drip tubing, $\$ 248.88$ /acre and $\$ 100.00 /$ acre, respectively (Smith and Taylor, 2003a) and the cost of land preparation, \$229.17/acre (S.A. Smith, personal communication) from the secondary crop. This represents a cost reduction of $4.8 \%, 10.8 \%, 11.7 \%$, and $23.2 \%$ for bell pepper, pickling cucumber, summer squash, and muskmelon, respectively (Hewitt, 2003; Smith and Taylor, 2003b, 2003c, 2003d). If the cost of production of bell pepper is further reduced by $\$ 715.20 /$ acre for fumigation (Smith and Taylor, 2003a), total cost reduction becomes $10.7 \%$. Fumigation was not removed from the cost of other crops because, when they are grown alone, soil fumigation is not always performed in Florida. These reductions of production cost can allow growers to reach break-even costs more readily and increase profits on secondary crops.
Relay-intercropping did not reduce strawberry yields with test secondary crops; therefore, this practice should not be considered a reason to invalidate insurance policies if performed within the last 4 weeks of strawberry production. However, great care should be taken to apply pesticides that are labeled for both crops planted together in the field. Furthermore, relay-intercropping is a management strategy that can increase the utility of inputs in an annual-hill winter strawberry production system.

\section{Literature cited}

Brown, J.E., W.E. Splittstoesser, and J.M. Gerber. 1985. Production and economic returns of three vegetable double cropping systems. J. Amer. Soc. Hort. Sci. 110:414-417.

Coolman, R.M. and G.D. Hoyt. 1993. Increasing sustainability by intercropping. HortTechnology 3:309-312.
Hanna, H.Y. 2000. Black polyethylene much does not reduce yield of cucumbers double cropped with tomatoes under heat stress. HortScience 35:190-191.

Hewitt, T.D. 2003. Estimated cost of producing on acre of cantaloupe for fresh market, north Florida. 16 May 2005. <http://nfrec.ifas.ufl.edu/thewitt/entbud/budgetpage2.htm>.

Legard, D.E., G.J. Hochmuth, W.M. Stall, J.R. Duval, J.F. Price, T.G. Taylor, and S.A. Sargent. 2003. Strawberry production in Florida, p. 251-256. In: D.N. Maynard and S.M. Olson (eds.). Vegetable production guide for Florida. Vance, Gainesville, Fla.

Poling, E.B. and W.J. Lamont, Jr. 1991. A partial economic analysis of double-cropping annual hill plastic mulch strawberries with muskmelons. Adv. Strawberry Prod. 10:60-62.

Smith, S.A. and T.G. Taylor. 2003a. Strawberries, Plant City: Estimated production costs and net returns for various price and yield combinations. 16 May 2005. <http://www.agbuscenter.ifas.ufl.edu/ cost/cop02-03/Strawberries.pdf>.

Smith, S.A. and T.G. Taylor. 2003b. Summer squash, Dade: Estimated production costs and net returns for various price and yield combinations. 16 May 2005. <http://www.agbuscenter.ifas.ufl.edu/ cost/cop02-03/DadeSquash.pdf>.

Smith, S.A. and T.G. Taylor. 2003c. Green pepper, southwest Florida (single crop): Estimated production costs and net returns for various price and yield combinations. 16 May 2005. <http://www.agbuscenter. ifas.ufl.edu/cost/cop02-03/SWPeppersSC.pdf>.

Smith, S.A. and T.G. Taylor. 2003d. Cucumber, southwest Florida: Estimated production costs and net returns for various price and yield combinations. 16 May 2005. <http://www.agbuscenter.ifas.ufl. edu/cost/cop02-03/SWCucumbersDC. pdf $>$. 